\title{
- Um crítico em três atos
}

\section{Roberto Sarmento Lima}

Professor Associado 3 e doutor em Literatura

Brasileira na linha de pesquisa Literatura e

História, lotado na Faculdade de Letras da

Universidade Federal de Alagoas, onde ensina

a disciplina Teoria da Literatura, na graduação

em Letras, e a disciplina Fundamentos Teórico-

Filosóficos da Literatura, no Programa de Pós-

Graduação em Letras e Linguística.

Resumo: Discussão a respeito do papel da crítica literária contemporânea, que, de acordo com 0 veículo em que apareça, assume configuração distinta, ainda que se trate do mesmo autor. No caso, o crítico focalizado é Roberto Schwarz, que, em três momentos de sua produção intelectual, escrevendo em livro de ensaios, em revista não especializada e em suplemento de jornal, é guiado ora por forte pendor metodológico, ora pelo descompromisso com a linguagem acadêmica, 0 que o conduz, por vezes, ao elogio fácil do objeto analisado e ao desvanecimento do ato crítico, beirando o impressionismo, que hoje se julga superado.

Palavras-chave: Crítica contemporânea; crítica de jornal; crítica acadêmica
Résumé: Dans cet article on discute le rôle de la critique littéraire contemporaine, qui, vu le véhicule choisi pour sa divulgation, présente une configuration distincte, même sill s'agit du même auteur. Ici, le critique étudié est Roberto Schwarz, qui, au cours de trois moments de sa production intellectuelle, soit publiant des essais, soit écrivant pour les revues non spécialisées, soit pour les rubriques littéraires des quotidiens, semble tantôt guidé par une forte tendance méthodologique, tantôt libéré de toute compromission avec le langage académique, ce qui le mène parfois au compliment facile de l'objet analisé, à l'affaiblissement de l'acte critique, proche de l'impressionisme, censé aujourd'hui depassé.

Mots-clé: Critique contemporaine; crítica de journal; critique académique 



\section{Introdução}

Muito se fala na crise por que passa tanto a literatura como a própria crítica literária, desde as últimas décadas do século XX aos dias que correm. Razões podem ser apontadas a mancheias: crise dos valores sociais na contemporaneidade; avanço célere da tecnologia das demais mídias, com que a literatura compete; consequente descaso para com a leitura de modo geral, da leitura da literatura em particular; até mesmo despreparo do crítico, hoje menos erudito do que foi um dia, mas também, em troca, mais especializado na matéria; agigantamento da necessidade profissional de produzir e as precariedades que, num espaço curto de tempo, isso acarreta, tendo em vista a própria precipitação em publicar, por pressões acadêmicas e institucionais, sacrificando, assim, a validade ou a profundidade do arrazoado que se assina. Note-se que esse contexto de lamentações só atinge a crítica porque, antes disso, já atingiu a literatura e, assim, é favorável a que apareça, como pretendo situar o presente estudo, a crítica da crítica da literatura, fato tão bem lembrado por Benedito Nunes (2000, p. 70). No entanto, quero crer, ao conduzir a argumentação que se vai expor a partir de agora, que a propalada "crise" é tão somente o reposicionamento, no mundo atual, tanto da literatura quanto da crítica, situação que, de início mal compreendida, desconcerta, angustia, mas que, com a continuidade e rotina dos procedimentos, termina por se explicar, deixando-se absorver pelo sistema literário como um todo.

Por outro lado não se pode negar que, com o crescimento dos programas de pós-graduação nas universidades brasileiras - com o fortalecimento da chamada "crítica universitária", pelo menos mais intensamente desde a década de 1950, cujo grande defensor foi Afrânio Coutinho, que se colocou contra a crítica dos jornais e periódicos não especializados - 
aparecem hoje, cada vez mais, trabalhos ensaísticos decorrentes de aproveitamento de teses de doutorado, por exemplo. Em posição diametralmente oposta, os suplementos literários de jornais, outra via crítica, já não são tantos; alguns são até sofríveis. O crítico-jornalista, que já, um dia, foi mais denso e penetrante, tornou-se, hoje, para melhor se comunicar com o público a que se dirige, um facilitador no mau sentido do termo, fazendo definhar o rigoroso trabalho de análise e ajuizamento do texto. Parece que, como diz Brás Cubas, havia e há, no Brasil, "duas colunas máximas de opinião": o crítico vindo das universidades e o crítico dos suplementos de jornal. O que não quer dizer, por força da comparação, que nelas se abriguem respectivamente "os graves" e "os frívolos". Mas, algum tempo atrás, em um cenário visualizado por Afrânio Coutinho (um scholar declarado), os dois grupos eram, sim, contrastantes e viviam em clima de guerra, lembrando a atmosfera do conto "Duelo", de Guimarães Rosa (SÜSSEKIND, 2003, p. 24). Hoje, relativizando-se as diferenças, estas se mostram um tanto indistintas, e o clima é de franco compadrio.

O que tem o ar de ser uma contenda fácil de analisar - pois (qual é o mal?), de um lado, estão, desde as décadas de 1940 e 1950, os críticos vindos dos jornais e dos rodapés, sem a formação universitária própria para a atuação do crítico, e, de outro, o críticoprofessor universitário, armado até os dentes com teorias e terminologias sedutoras aprendidas nos bancos das graduações e pós-graduações em letras (há lugar para todos sob o sol) - coloca-se, entretanto, como uma questão que se atualiza, sob novos parâmetros, neste momento das indecisões planetárias. Confundem-se hoje o crítico especializado e o crítico pouco ou nada especializado nos jargões das letras, podendo os dois tipos conviver em um mesmo crítico, como o Mr. Hyde e o Dr. Jekyll. Nada contra, aliás. O que parece constrangedor é que a atuação do crítico em dois canais distintos, a universidade e o jornal, terminou por fazer a atividade decair. Ou, então, mudar de rumo e redefinir seu papel. 
É isto - esse panorama geral de descrédito e estiolamento da atividade crítica - que pretendo discutir mais de perto neste artigo. E, para não fugir do hábito das comprovações, que, ao menos didaticamente, servem para sustentar os argumentos apresentados, escolhi um crítico em atividade, de peso no cenário da crítica nacional, que tanto escreve ensaios publicados em livros, quanto artigos para jornais. Trata-se de Roberto Schwarz, que examinarei em três atos, como indica o título: em três situações diferentes. Uma, tomando como base o ensaio "Complexo, moderno, nacional, negativo", sobre o romance Memórias póstumas de Brás Cubas, de Machado de Assis, publicado em Que horas são?, de 1987; outra, através do artigo publicado na revista Piauí, "Casmurro abre o jogo", em dezembro de 2008; e, por fim, o esquadrinhamento de um artigo publicado em 28 de março de 2009, no caderno "Ilustrada", da Folha de S.Paulo, intitulado "Brincalhão, mas não ingênuo", sobre o romance Leite derramado, de Chico Buarque, para cujo contraponto escolhi o seu companheiro de página, o economista e cientista social Eduardo Giannetti, que também discorre sobre esse romance.

Tentarei ver, pois, como em um mesmo crítico se desenvolvem ao menos duas - depois concluiremos que, na verdade, são três - atitudes, como se se tratasse de dois (ou três) intelectuais diferentes escrevendo. Mas fundamentalmente há dois perfis básicos: de um lado, o rigor na construção metodológica que preside a análise literária, algo peculiar ao crítico scholar, especializado, que teve alta formação científica, própria do ambiente universitário, preparada no contato com estudos feitos em cursos de graduação e pós-graduação ao longo de uma carreira prestigiosa; e, de outro lado, a atitude um tanto descompromissada com o rigor analítico que caracteriza o crítico ligeiro, se podemos assim chamar ao crítico de jornal, mais interessado na repercussão que o livro examinado obtém no mercado livreiro, atendendo, assim, às expectativas da editora, do jornal e do público, nessa ordem, do que propriamente preocupado com 
a atividade crítica na qual se formou e solidificou sua imagem de intelectual.

São duas maneiras de enxergar e executar o ato crítico - de um lado, a crítica metodologicamente orientada, com apoio forte em teorias científicas em que se funda a análise da literatura, em consórcio com outras disciplinas das humanidades, cujo suporte material é o livro; e, de outro, a crítica de divulgação, mais do que de ajuizamento, de uma obra, sem recorrer aos jargões da teoria literária, cujo meio impresso é o jornal. Entre elas duas interpõe-se um segundo tipo, mediano e de posição intermediária, com marcas discursivas tanto do primeiro tipo quanto do segundo tipo, o qual, aqui, denomino de crítica maneirista. Nesta, que fica entre o livro (o primeiro tipo) e ojornal (o terceiro tipo), tenta-se ainda manter a aura de crítica científica, com atenção dada ao julgamento, mas também com tendência acentuada a tornar mais rarefeita a fundamentação teórica, assumindo, por momentos, o tom leve da crítica pronta para ser publicada em jornais. Não sem razão é que esse segundo tipo se publica, em geral, em revistas, não em jornais; em revistas que se vendem em bancas, porque, materialmente falando, ela se coloca entre o livro, feito para durar em bibliotecas, e o suplemento de jornal, que não tem a sacralidade do livro mas, sim, o caráter de descartável, a começar pelo tipo de papel utilizado na sua confecção. Já a revista, com seu papel diferenciado, com capa de imagens coloridas, pode ser armazenada de forma mais cuidadosa, atraindo o leitor pela diagramação, pelos quadros, pela conjunção das artes técnicas da fotografia, do desenho e da publicidade.

Se se levar em conta o fato de que a mudança de suporte material (o livro, a revista não especializada, o jornal) influi, com seus variados recursos físicos, na organização da escrita do texto, é esperável que a sua produção como texto em si seja alterada e, assim, seja alterada também e consideravelmente a relação que se estabelece entre o autor, o texto e o público. Como se pode ver mais concretamente no hipertexto eletrônico, muitas vezes, mesmo que o autor não seja compreendido 
como elemento estruturante da comunicação escrita - afinal, na maioria das vezes, independentemente de quem assina, qualquer um da área poderia ter dito o que está dito - , arrisco-me a dizer que, ainda assim, deve ser pensada a posição do autor do texto no sistema literário, embora a opção por este ou aquele suporte libere o articulista (no caso do texto ligeiro) da necessidade de fundamentar teoricamente a análise ou (no caso do livro) o mantenha preso aos mais elevados níveis intelectuais da produção textual. O que, na verdade, vem a contribuir - no caso específico da revista e do jornal - para certa descaracterização do ato crítico ou, melhor dizendo, para a sua renovação e transformação desse produto, infelizmente, em um produto rebaixado. Até que ponto o autor é um autor, com nome e identidade firmada e distinta, se o papel institucional e midiático no qual se publica é forte o suficiente para definir o "em-si" da atividade crítica? É o que se verá a seguir.

\section{Primeiro ato: rigor metodológico}

Em um primoroso ensaio publicado no livro Que horas são? (1987), "Complexo, moderno, nacional, negativo", Roberto Schwarz analisa a composição do romance Memórias póstumas de Brás Cubas, motivo de desacordos entre tantos críticos machadianos, que terminaram por desqualificar, sem entender bem a proposta dessa obra, o método compositivo de que se serviu, muito inovadoramente na sua época, o romancista carioca. A crítica de Schwarz vem, como ele mesmo declara, "em direção oposta, e diz que há método nas manhas narrativas do romancista" (SCHWARZ, 1987, p. 115).

O crítico cita Otto Maria Carpeaux e, com destaque, Augusto Meyer para sustentar seu ponto de vista, ainda que se coloque em oposição a todos os críticos do passado e a esses dois particularmente. No entanto, volta à noção de "volubilidade" de Meyer para, renovando o conceito, mostrar, com lucidez, que a forma narrativa desse romance de Machado "formaliza e expõe 
em sua consequência dinamismos decisivos da realidade brasileira", dentro daquilo que ele entende ser resultado de uma pesquisa fundada na chave explicativa da crítica dialética, mostrando a inter-relação entre a forma literária e a organização do nosso processo social, desde, pelo menos, o século XIX.

Nesse artigo, Schwarz busca compreender o "princípio formal do livro" (SCHWARZ, 1987, p. 119), apontando a originalidade de Machado de Assis em face da prosa ficcional europeia de sua época, os grandes romances realistas. Talvez o único rastro de Lukács nessa análise (por sinal, citado apenas uma vez) seja justamente a consideração disso, o "realismo" na literatura oitocentista, com o qual confronta a construção de Memórias póstumas, confirmando, na prática da leitura do romance, o quanto de energia pessoal e de talento de Machado de Assis se concentra nessa obra, e, no caso do crítico Schwarz, pela sua ótica inovadora de análise, o quanto há também de criativo na investidura de tal compreensão. Parco de citações, esse ensaio, um dos mais bem-arquitetados por RobertoSchwarz, revela-se maduro sobretudo por se poder detectar, nele, uma espécie de crítica do autor, carimbo de uma autoria que o solidifica no sistema de ideias críticas e o faz ser reconhecido na crítica nacional moderna, algo a ser notado já pelas primeiras palavras escritas. Crítica do autor que, entretanto, muda de configuração quando muda o veículo de publicação...

A admiração que causou esse ensaio, em dezembro de 1981, no primeiro número da revista especializada Novos Estudos Cebrap, antes de ir parar na coletânea Que horas são?, de 1987 — até este momento já são decorridos vinte e nove anos - , fica preservada. E, neste tempo todo, o mesmo brilho mantém-se, o que só faz aumentar a força, aliás, da sua eficácia interpretativa, porque, como se pode ou costuma dizer, se trata de um estudo que já nasceu clássico, dada a importância, para a fortuna crítica de Machado de Assis, de uma leitura sociológica não mecânica, mas muito atenta, como ensina Antonio Candido, à noção de forma. Nele conjugam-se 
admiravelmente bem, como é de esperar de um crítico experiente, atenção à percepção do mundo concentrado no romance, com todas as implicações que isso traz, e a capacidade de dar conta de, analisando bem o material que tem à mão, promover uma síntese estética que, antes de tudo, cabe à arte operar, com base nos elementos externos que se imiscuem na tessitura narrativa, como fica muito bem demonstrado na análise.

Schwarz investiga o tecido do romance machadiano, iluminando seus aspectos formais mo âmbito da composição do texto, na qual "a crítica viu um ponto fraco", mesmo quando quem o afirma é a ótica privilegiada de Meyer. Schwarz segue palmilhando pouco a pouco os conteúdos do livro, conectando-os com o levantamento de seus traços mais técnicos, até desembocar naquele achado de Meyer, "a volubilidade de seu narrador". O "virtuosismo retórico" de Brás Cubas, com suas "viravoltas sobre viravoltas", tem, por conseguinte, nessa interpretação, um respaldo na vida social brasileira, à medida que salienta, naturalmente, o projeto escritural machadiano, o seu esforço de planejamento de construção romanesca:

Noutras palavras, Machado ajustou um procedimento artístico no qual a realidade burguesa corrente, em qualquer uma de suas expressões, seja ideológica, sintática, estética etc., é regularmente sujeitada à veleidade pessoal, sem que no entanto o processo se complete. Uma tal forma naturalmente é um feito de construção, e pouco tem de espontânea. No resultado, a semelhança com a vida brasileira do século XIX é grande. É um exemplo de travação construtiva da mimese, ou por outra, da complexidade dos requisitos formais do efeito realista. (SCHWARZ, 1987, p. 121).

Aqui, por essa síntese, encontra-se o crítico em uma atuação que o consagrou como crítico da literatura, mostrando que, a par de um forte conhecimento 
epistemológico da sociologia e da estética, a obra analisada é compreendida em sua integridade, pondo em relevo seus aspectos essenciais, os artísticos acima de tudo. Quanto a isso, os leitores de Roberto Schwarz nada estranham, até se comovem, por vezes, com tamanha engenhosidade crítica.

Mas vamos ao segundo ato: o crítico da revista, a crítica que aqui chamo de "maneirista", que, se por um lado tenta manter a aura do discurso acadêmico, não raro, porém, dele se distancia - numa dosagem equilibrada ao entrar na arena do discurso jornalístico.

\section{Segundo ato: relaxamento metodológico}

Schwarz volta ao Machado de Assis de sempre, seu objeto compulsivo. Na edição de dezembro de 2008, a revista Piauí traz, provavelmente por motivo de homenagem ao centenário do escritor, o artigo "Casmurro abre o jogo", em que o crítico analisa apenas um capítulo do romance Dom Casmurro, o primeiro, chamado "Do título". Com uma paráfrase inicial do conteúdo desse capítulo, tendo sabido selecionar bem o léxico e optar por uma sintaxe mais direta, mais econômica e menos carregada de orações subordinadas, bem ao estilo jornalístico, Schwarz conclama o leitor para, juntos, de maneira envolvente, valorizar o que poderia até passar despercebido:

Não vamos esquecer que essa passagem é uma explicação do título do livro, oferecida pelo próprio autor, ou pseudo-autor. De início assistimos à tensão ligeiramente cômica entre dois cavalheiros num vagão de trem, uma espécie de guerrilha de esnobismo. (SCHWARZ, 2008, p. 58).

Schwarz não cita autores, como o faria em um ensaio publicado em livro; também não mostra sua habitual marcação de uma leitura ideológica, fundada em geral no marxismo, terreno em que pontifica embora, em uma coletânea de ensaios publicada em 1999, 
Sequências brasileiras, tenha sido capaz de reconhecer que "o marxismo está em baixa e passa por ser uma ladainha" (p. 86). Atém-se, nesse artigo da Piauí, à cena extraída do romance como o faria um observador meticuloso, de mentalidade detetivesca, numa atitude que se aproxima muito do método da estilística ao focalizar um pormenor que vale todo o livro. Demora-se na paráfrase, que se torna, aliás, necessária para esse tipo de publicação, porque, para quem, excepcionalmente, não leu Dom Casmurro, o resumo ajuda a compreender, parecendo até o relato de um cronista que viu de perto a cena selecionada e a quer repassar ao leitor com o máximo de fidelidade. Não faltam também expressões típicas de um discurso oral, como se Schwarz estivesse, mesmo, ao pé de um ouvinte, não exatamente diante de um leitor, forcejando com este um pacto comunicativo que talvez não encontre paralelo nos seus textos de feitio acadêmico mais rigoroso:

Pois bem, o viajante mais velho não se zanga e conta a história de suas desventuras de bairro aos amigos elegantes que vivem no centro. As futricas da periferia são assunto de conversação para a gente superior. Por sua vez, os amigos elegantes também se divertem com o apelido e passam a usá-lo. (SCHWARZ, 2008, p. 58).

À maneira, mas somente à maneira mesmo, de uma crítica escolástica, sem com esta confundir-se, Schwarz vai discutindo a questão literária aos poucos, sempre, porém, como um articulista que evita cansar o seu leitor - eis a razão por que declina de uma reflexão mais pesada, mais apurada do ponto de vista terminológico e científico. Abrandando a linguagem de que se serve, já que o público da revista Piauí não é necessariamente formado por especialistas da área de letras, a análise ganha com isso em "leveza", além de a comunicação com o homem comum, o não especializado na área, sair fortalecida. Para tanto, para facilitar, enfim, o pacto com esse leitor indiferenciado, quase um ouvinte, não faltam redundâncias nem explicações didáticas comezinhas, que 
se podem ver nas expressões "Noutras palavras, a distância que o primeiro cavalheiro..." ou "Recapitulando, o apelido se deve...", próprias de quem quer ser exaustivamente compreendido, como se se tratasse de discurso oral, direto, sem a intermediação da escrita. Nesse pormenor, não faltou sequer um termo de baixo calão, como se a conversa se desse em um botequim:

Aí estamos, no mundo desconfiado e brutal das obsessões patriarcais, em que a humanidade não é composta senão, com perdão da palavra, de filhosda-puta. (SCHWARZ, 2008, p. 59).

Entende-se que a crítica hoje exercida em revistas não especializadas academicamente e também em jornais, por meio de seus suplementos ditos "literários", não tem mais a característica fundamental daquela que, muitas décadas atrás, foi desenvolvida e praticada por literatos ou jornalistas de formação erudita. A notória separação que se foi fazendo ao longo do século XX entre escritor e jornalista definiu os campos discursivos, fato que, no século anterior, mostrava feição bem diferente:

A imprensa do início do século XIX foi toda marcada pela atuação de escritores que, naturalmente, aproximavam a linguagem do livro à linguagem do jornal. Literatura e jornalismo se confundiam tanto que, basta lembrar, várias obras clássicas nasceram nos jornais, na forma de folhetins, como foi o caso da produção de José de Alencar e do próprio Machado de Assis (NINA, 2007, p. 19).

Ademais, em tempos de internet, como seu corolário e agravante, a comunicação ligeira e apressada tornou-se praticamente obrigatória, constituindo a pressa um componente do estilo, com influências no campo da escrita e da reflexão. Talvez até se deva mesmo encarar isso como elemento compositivo do texto de jornal, da mesma forma que, por exemplo, a tecnologia mais primária do cinema faz parte, constitutivamente, dos filmes mudos e 
em preto e branco e é assim que eles devem ser apreciados. Colorizar esses filmes é descaracterizá-los, corromper uma técnica, mudar-lhes a informação. A arte, enfim, não evolui; ela tem estágios nos quais deve ser compreendida integralmente, sem confronto de um estágio com outro. Igualmente, os suplementos literários, em tempos de tecnologia mais avançada, de internet, de mídia eletrônica, apresentam um perfil que lhes é pertinente nesta época, presentemente, e talvez por isso estejam redefinindo a crítica literária.

A propósito mesmo da internet, assim se posicionou o jornalista potiguar Carlos Magno Araújo:

Se estudado daqui a algumas décadas, o período em que vivemos certamente será citado como uma espécie de divisor de águas. Foi quando, temendo a concorrência da mídia eletrônica, os jornais radicalizaram na sua maneira de informar. Os textos deveriam ser mais curtos. Os assuntos, mais do que nunca, tratados superficialmente. (ARAÚJO, 2002, p. 93-94; o grifo é meu).

Tal situação também não poupa de modo algum, nem poderia eximir desse estado de coisas, o artigo ou o ensaio do suplemento literário publicados, respectivamente, em revistas não especializadas e em jornais, por meio dos seus suplementos. O que Schwarz faz, pois, é aclimatar-se aos novos tempos, não por algum despreparo ou falta de condições intelectuais para compor páginas com maior fôlego analítico-metodológico, algo que se coloca definitivamente fora de questão. No contexto atual, em críticos formados no terreno próprio da revista, aqueles que só atuam nesse tipo de veículo e geralmente fazem resenhas de obras de ficção para orientar o leitor o que não é o caso, decididamente, de Roberto Schwarz -, é que melhor se percebe o pouco (ou reduzidíssimo) manejo, apesar de alguns vislumbres interpretativos, do referencial atinente à teoria da literatura. Poderia, aqui, pinçar um fragmento da revista Veja, em sua coluna semanal "Livros", para mostrar a rala atenção que se dá ao 
emprego dos termos técnicos e da nomenclatura específica, o que é indício de desatenção para com a teoria:

O enredo é secundário: resume-se à luta de tal mulher forte por justiça (ou vingança: o vilão deve ser castigado). Tenha em mente que justiça não é justiça sem compensação financeira. A heroína deve chegar às últimas páginas montada no dinheiro (VOVÔ best-seller, 2004, p. 156; o grifo é meu).

Inconcebível seria, se fosse o caso de um crítico universitário, referir-se ao "enredo" como a parte secundária de uma narrativa a ponto de, com esses dados, poder fazer um "resumo" na hora de mostrar ao leitor a matéria de que trata a obra. Fora do alcance terminológico, restrito ao senso comum, o conceito de "enredo" é, em geral, confundido com o de "história"; e é o que se vê, quase que absolutamente, nos textos críticos de revistas e jornais, isso sem falar das salas de aula de literatura no ensino médio e nos cursinhos preparatórios do vestibular, onde o descalabro é grande no que diz respeito à exposição e decifração dos conceitos básicos. Fora a expressão corriqueira "a heroína montada no dinheiro", como, em geral, se diz por aí, o texto de Veja corporifica a tendência atual de tratar de literatura, em revistas e jornais, sem cuidado teórico nenhum, chegando mesmo a desvirtuar a terminologia básica. No caso de Schwarz, sempre atento aos conceitos e às categorias da área da teoria literária, fica apenas evidente a marca de certa influência do modismo da simplicidade expressional, como o comprova a presença de termos populares e descontraídos: o "Pois bem", "as futricas" e os "filhos-da-puta" que destaquei acima.

Não que a liberdade ou a espontaneidade expressional devam ser banidas de textos mais exigentes e complexos; não, de forma alguma. Creio até que os tempos de Álvaro Lins (não especializado na área da teoria literária, embora competente no que fazia) e de Afrânio Coutinho (defensor ferrenho da especialização 
do scholar) não existem mais, por todas as transformações que a sociedade planetária vem sofrendo. Não há lugar mais nem para o beletrismo nem para o encastelamento do crítico, que deve mesmo dialogar com os leitores mais variados, podendo escrever em livro ou em artigos de revistas e jornais, dando-se isso em regime de interação, intercâmbio e interinfluência, uma vez vencidas, pois, as fronteiras rígidas. Afinal, como afirma Eneida Maria de Souza,

Muda-se portanto o enfoque: se antes a crítica de rodapé cedia lugar à universitária, criando-se um abismo entre a academia e a mídia, hoje o discurso crítico se nutre dos meios de comunicação de massa, através da apropriação dos procedimentos e da dicção enunciativa. A elitização cultural não mais se sustenta diante do apelo democrático dos discursos, razão pela qual a literatura deixa de se impor como texto autônomo e independente - se é que algum dia ela assim pôde ser vista. (SOUZA, 2007, p. 20).

Mas este não é o problema, a "dança das cadeiras do crítico", ou a chamada democratização dos seus recursos enunciativos em razão da passagem de um suporte a outro (do jornal para o livro e vice-versa). Hoje, aparentada dos discursos não científicos da mídia eletrônica (os blogues estão aí para confirmar isso), a crítica renova-se, não mais se sustentando, como diz Souza, a elitização da atividade. Para o argumento que aqui defendo, não se trata tanto assim de mera mudança de enfoque ou de reconhecimento de que os discursos, alto e mediano, cada vez mais se cruzam. O que ocorre, na verdade, é outro problema: o rebaixamento da qualidade do ato crítico, o seu flagrante definhamento. Se o intercâmbio de discursos e de lugares discursivos é até saudável, e acho que é realmente, não se deve pretender que, por um equívoco qualquer de interpretação, seja justificado, como corolário, o abastardamento do ato crítico. O que não deve é haver, nesse contexto, nem a defesa cega do elitismo nem do 
adelgaçamento da linguagem especializada do crítico, dois perigosos extremos.

O mais grave é que a situação atual da crítica praticada nos meios impressos que não o livro vem habitual e deliberadamente assinalada por profundo desleixo teórico-metodológico, como se, para ser compreendido, o crítico tivesse de recuar do seu papel e do amparo dos critérios de validade heurística que uma atividade dessa natureza requer. O que se deveria evitar é o descompromisso para com a própria qualidade do ato crítico, para que a análise não beire o impressionismo, a crítica do gosto, a subjetividade incontrolada, a falta de uma razão eficiente para a declaração do juízo.

Mas o pior ainda está por vir. Quando se sai do livro especializado, onde se pratica a crítica, digamos, mais ortodoxa, e da revista de grande público, onde se faz uma crítica maneirista, e, por fim, se entra no jornal, as qualidades do discurso apontadas até este momento - a descontração linguística, a falta de atenção com a teoria e a terminologia crítica, o tom de conversa ao vivo tendem a acentuar-se e derivam para o definhamento do próprio ato crítico mais ortodoxo.

\section{Terceiro ato: aniquilamento metodológico}

Surpreendamos Roberto Schwarz em uma página de jornal, colhida do caderno "Ilustrada" da Folha de S.Paulo, o sábado 28 de março de 2009. No artigo intitulado "Brincalhão, mas não ingênuo", Schwarz analisa o romance Leite derramado, de Chico Buarque. Assim começa o artigo, que, bem ao estilo desse crítico, já relaciona matéria literária à realidade social brasileira:

"Leite derramado" é um livro divertido, que se lê de um estirão. O título refere-se a um casamento estragado pelo ciúme e, indiretamente, ao curso das coisas no Brasil. Aos leitores mais atentos o romance sugere uma porção de perspectivas meio escondidas, que fazem dele uma obra ambiciosa. Os amigos de Machado de Assis notarão o paralelo 
com "Dom Casmurro". (SCHWARZ, 2009, p. 6; o grifo é meu).

A comparação estabelecida, de cara, entre Leite derramado e Dom Casmurro parece um tanto forçada, como se, pela aproximação de um com o outro, o romance de Chico Buarque ganhasse prestígio, ao tornar-se, por essa menção, provável herdeiro do brilho de um mestre da arte da narrativa ficcional. No entanto, em tudo Matilde e Capitu divergem, a não ser pelo presumido adultério (muito pouco, não?), também relatado por um narrador velho e doente de ciúme, de quem sempre se pode desconfiar: mas, enquanto Capitu se amoldava, ao menos na aparência, a um estilo de vida burguês, adquirindo modos e gestos de quem, educada ou reeducada nessa camada social, podia até encontrar quem a defendesse da acusação feita por Bentinho, dada a sua capacidade, também presumida, de dissimulação, a Matilde de Leite derramado, ao contrário, é de uma vulgaridade flagrante e de atitudes indefensáveis do ponto de vista do padrão social dominante:

Entre as façanhas da narrativa está a figura de Matilde, uma garota incrivelmente desejável feita de quase nada. Quando ela entra no mar, daquele jeito dela, é "como se pulasse corda". "Saía da igreja como quem saísse do cinema Pathé" e circulava pela fila de pêsames "como se estivesse numa fila de sorveteria”. [...]

[...] Por sua vez, o feitiço irreverente de Matilde, entre modernista e patriarcal, também foge ao decoro: a esposa perturbadora não tem ginásio completo, é mãe aos 16 anos e assobia para chamar os garçons, além de ser aluna-problema do Sacré Coeur e congregada mariana. (SCHWARZ, 2009, p. 6).

É mais fácil, dada a composição desse perfil de mulher, acusá-la de adúltera do que aquela outra, a de "olhos de ressaca", que sabia, como ninguém, manipular 
os instrumentos da convenção social assim como um peixe nada confortavelmente em uma piscina. Pode-se aventar a ideia, por sinal muito recorrente em crítica literária, que o romance de Chico Buarque "lê" parodicamente Dom Casmurro, tratando-se de configurar pelo avesso, nesse possível intertexto, uma das mais famosas personagens femininas machadianas. Matilde é a mal-educada, a brejeira, a "escurinha" (como está no romance), aquela de pouco ou nenhum refinamento social; acrescem-se a isso sua aparência e sua origem sem matiz aristocrático, do que resulta sua maior inclinação para o Leonardo das Memórias de um sargento de milícias, de Manuel Antônio de Almeida, do que, mesmo, para a nossa velha conhecida Capitu, a respeito de quem pululam dúvidas:

Entre várias irmãs claras, Matilde é a única escura, para desgosto da sogra, que entretanto tem um irmão beiçudo. Mais adiante se saberá que a moça é filha adotiva duma escapadela baiana do pai. Os seus conhecimentos de francês e a sua cultura geral deixam a desejar, envergonhando o marido, que nos momentos de ciúme acha que casou com uma mulher vulgar. [...] Em plano diferente mas aparentado, a pele "quase castanha" da menina combina com cetim laranja, o que deslumbra e enfurece Eulálio, que preferiria que ela usasse roupa mais fechada, de tons mais discretos. (SCHWARZ, 2009, p. 6).

O afã de relacionar os dois romances, o de Chico Buarque e o de Machado, leva o crítico, numa atitude pouco reflexiva, a adotar um campo de visão que as enunciações narrativas não contemplam, pelo menos a esse ponto (mais adiante examino a abordagem de Eduardo Giannetti sobre o mesmo romance e detecto nele certa incredulidade ao estabelecer essa filiação literária, embora a faça sem pestanejar). Enquanto Bento Santiago é um homem encerrado nele mesmo, tornandose casmurro, vivendo de rememorar o passado, o falante Eulálio Assumpção, "que fala pelos cotovelos", pensa 
em mulheres, conquistas, frivolidades. Será que, como afirma Schwarz, o fato de ser a personagem central o narrador da história (algo comum a Eulálio e a Bentinho) é suficiente para assegurar a presença de uma "situação literária machadiana, em que a crítica social não se faz diretamente mas pela autoexposição 'involuntária' de um figurão" que, "recapitulando sua vida com propósito sentimental", serve de instrumento ao ficcionista para desancar o patriarcalismo? Até que ponto a armação de uma personalidade funciona como produto alegórico do país, neste e naquele romance? Não terá sido o desejo de Schwarz de conferir ancestralidade notável ao romance de Chico Buarque, tentando alçá-lo à condição de grande ficcionista contemporâneo, que forçou, forjou o enlace entre os dois textos? Ou, então, não estaria, antes, Eulálio, se se quer mesmo insistir no rastro machadiano, seguindo as pegadas do memorialista Brás Cubas, de quem parece mais próximo, e não tanto do memorialista Casmurro, um homem já sem libido para se expor assim tão abertamente?

Assim, quando perde o pai, Eulálio trata de lhe seguir os passos ilustres. Enverga uma das gravatas inglesas do senador, vai tomar cafezinho com políticos nos respectivos gabinetes, passa pelo escritório da Le Creusot, a firma francesa cujas negociatas o grande homem facilitava, leva bombons à secretária, fuma uns charutos, dá uma chegada ao banco e antes das quatro volta para casa. (SCHWARZ, 2009, p. 6).

Pode-se dizer tudo de Bentinho, menos que ele seja um mulherengo e um fraudador da vida e das convenções sociais, das quais, aliás, por querer ser o seu guardião, se sentia vítima. Eulálio não é um Bentinho; é, antes, da família de Brás Cubas, como já observei, e Matilde, por seu turno, é uma Rita Baiana, apequenada talvez, mas igualmente mecânica em seu retrato. O que ela não tem, decididamente, é a composição de Capitu. 
O próprio título do artigo de Roberto Schwarz, "Brincalhão, mas não ingênuo", talvez já possa dizer tudo. Brincar com a vida não é façanha de Bento Santiago, que não se diverte com nada nem com ninguém, muito menos com a própria sorte. Ademais, se Capitu compete com Bentinho o direito de ser protagonista, a Matilde de Chico Buarque não, pois desaparece inexplicavelmente, sem deixar pistas, e isso nem parece afetar o livro. Donde, pois, a necessidade da comparação? Famílias burguesas que se arruínam por dentro e por fora, com todas as mazelas - morais, econômicas, sociais e até estéticas —, se contam aos montes por aí, na literatura brasileira. Talvez a expressão mais dramática, como também a mais representativa, seja a Crônica de uma casa assassinada, de Lúcio Cardoso, em cujo enredo se cristalizam a patologia social mais densa, mas também a frivolidade e a apatia, além de distúrbios sexuais e comportamentais de suas personagens flagrantemente icônicas, quase à feição de um roman à thèse.

A pressa em ligar Leite derramado e Dom Casmurro talvez não ocorresse em ensaio publicado em livro. Eis a diferença do veículo que transporta os papers críticos. O mesmo, aliás, pode ser dito a respeito da ficção, como o esclarece Granja (2009) ao estudar o processo de composição de um conto de Machado de Assis publicado inicialmente no suporte folhetim de jornal. Mas o que é, hoje, o suplemento de jornal? Quem é o seu leitor? $\mathrm{O}$ artigo que se publica serve ao leitor ou, em primeiro lugar, à editora? Ou ao autor do livro? Como se pode, agora, caracterizar o texto crítico sem que se possam deixar de lado as determinações do meio impresso pelo qual aquele circula? Está a "verdade" do texto ligada ao suporte material do texto e ao seu modo de produção, podendo, pois, variar a interpretação de acordo com o suporte textual que o carrega?

Uma coisa é o livro, feito para durar, para ocupar espaço nas estantes, lugar que normalmente lhe é destinado, para um dia ser aberto e consultado quando a situação de pesquisa o requerer. Outra é o texto publicado 
em revista e em jornal, veículos perecíveis, se comparados ao livro, e também, por isso mesmo, um tanto subordinados às pressões do tempo da publicação, conforme o gosto do público a que se dirige tal texto, numa época em que o meio eletrônico está a todo vapor definindo os modos de recepção e, claro, de produção. Segundo reflexão feita por Silviano Santiago, hoje, quando se enfrentam a rapidez da informação e seu consumo imediato e sua morte consequente em favor do aparecimento da informação mais nova ainda, que passa, nessa sucessão de fatos, a ter vez - situação que corresponderia à "necessidade urgente de uma avaliação criteriosa da produção ficcional e poética contemporânea" - o preço disso pode ser justamente a "inevitável perda de rigor científico nas indagações de caráter teórico e metodológico", espécie de "custo intelectual que poderia ser compensado pela retomada pelos cidadãos dos valores maiores da tradição literária ocidental” (SANTIAGO, 2008, p. 157).

Não há como negar que a democratização da cultura - por meio da facilitação do acesso das camadas sociais, quaisquer que sejam, aos produtos da esfera erudita e, indiferentemente, da esfera popular e da cultura de massa - nem conseguiu promover a libertação do jugo dos critérios elitistas de produção artística, como um tempo aí se pensou entusiasticamente, nem cristalizou a decantada renovação da arte em razão do intercâmbio dos setores "altos" e "baixos" com a manutenção dos níveis de qualidade artística. Muitas vezes isso se deu de forma anárquica e parasitária (pense-se no romancereportagem da década de 1970, que é sempre visto como uma arte menor, justamente porque ainda imperam os critérios elitistas de julgamento). Ao contrário, esses diversos tempos e espaços culturais - o dos eruditos, o das camadas populares e o das massas - terminaram por se submeter, quando não se isolam completamente um do outro, ao primado do tempo industrial, gerando certa padronização de gosto e de manifestação do saber, passando o critério erudito de classificação a ser paródico de si mesmo. Isto é, finge-se que ele é aplicado com 
rigor, mas, na prática, ele apenas disfarça, e desculpa, as "imperfeições" do objeto avaliado, no caso da aplicação de uma leitura crítica. Isso, evidentemente, sacrificou a atividade crítica literária, que não poderia mesmo ficar alheia ao panorama geral como se habitasse uma torre de marfim. A "barbárie globalizada" (a expressão é de Leyla Perrone-Moisés, 1998, p. 203) instaurou o "vale-tudo ideológico e estético" (expressão também dessa autora), que, segundo ela, "prospera e aufere lucros, indiferente a qualquer teorização da crítica".

Não é isso, por acaso, que se reflete na composição do texto aqui analisado, o de Roberto Schwarz, cujas extrapolações - que não resistem a um exame mais apurado - saltam aos olhos, caracterizando o ato crítico quase como leviano, beirando o elogio fácil, pouco importando, desse modo, a legitimidade heurística? A supremacia, sobre o próprio saber, da indústria da editora e do jornal não tem definido, assim, o papel hodierno da crítica literária, influindo nos seus aparentes descaminhos?

Assim, se estou entendendo bem essa relação entre o ato crítico e a época social e cultural em que ele se realiza, por meios diversos de produção e divulgação, é a imprensa - e não o sagrado livro - que pode, por sua relação intrínseca com os meios hegemonicamente eletrônicos, estar trazendo sérios problemas à crítica como instituição. Santiago (2008), tentando reverter esse quadro pouco animador, exorta os professores universitários a ocupar o lugar que lhes cabe por direito e missão, ultrapassando as "quatro paredes do campus". A avaliação dos textos literários deveria, diz ele, ser praticada sistematicamente e cotidianamente por "especialistas com sólida formação disciplinar". Mas, se Roberto Schwarz é inquestionavelmente esse intelectual de "sólida formação" de que fala Santiago, o que haveria de errado com ele e com o texto que produz para o jornal? Assim, a causa não seria - além da pulverização do saber na sociedade dita pósmoderna, sob a influência da mídia televisiva e eletrônica - a preeminência gritante assumida pelo veículo sobre o 
processo de produção intelectual, que, desse jeito, revela não estar de fato imune às injunções sociais? Não seria, pois, nesse caso, tanto o autor o grande responsável, mas, sim, o meio ou suporte físico (o jornal, no caso) que ele aparentemente instrumentaliza, se é que o crítico não é pelo meio instrumentalizado.

Talvez valha a pena, por comparação, ir ao artigo de Eduardo Giannetti, economista e cientista social, de 52 anos (como faz questão de informar o caderno "Ilustrada"), atualmente professor do Ibmec São Paulo. O artigo, intitulado "A vida desde o fim", cuja publicação se dá nesse mesmo espaço da Folha, fica exatamente na página ao lado do artigo de Roberto Schwarz. Chamo atenção para a formação de Giannetti, neste caso, porque, comparando-o a um crítico nacional de peso, que é Roberto Schwarz, tudo poderia levar a crer que o argumento crítico desenvolvido pelo economista sobre Leite derramado seria menos aquinhoado - pura presunção, sem conhecimento do fato - do que o do experiente crítico e professor universitário. Vamos, pois, aos fatos!

Apesar de tachar o romance de Chico Buarque de "obra de alta carpintaria literária", Giannetti não parece convencido disso - chega a dizer que, nele, há "soluções felizes de linguagem espalhadas como dádivas pelo texto" (o grifo é meu), o que soou irônico. Mas, apesar dessas soluções felizes, "o todo é menor do que a soma das partes". Diante de tal declaração, nem parece tão entusiasmado assim para, após a resenha, classificar o livro de "ótimo", como o fez Schwarz. Menos à vontade, contenta-se com o rótulo "bom" e talvez com isso quisesse dizer outra coisa.

Como Schwarz, Giannetti, em seu argumento, também alude a uma possível ligação, a certa familiaridade entre Leite derramado e Dom Casmurro: "As pegadas de 'Dom Casmurro' surgem a cada passo do livro", denotados, por exemplo, no "parentesco Eulálio-Bentinho e MatildeCapitu”. Estranha conexão essa: Eulálio-Bentinho, Matilde-Capitu. Por que será que insistem tanto nela, ao menos em artigos presumidamente mais rasos, como os 
de jornal? Giannetti, sempre muito arguto, entretanto, pressupõe que o gênero ensaio de jornal não merece tanta confiança assim por parte do leitor, porque isso tudo que se diz, no âmbito do suplemento, "seguramente dará ensejo [ainda] a rica produção acadêmica", que poderá ou não confirmar tal hipótese (a meu ver, fragílima, apareça onde aparecer: a ser assim, qualquer mulher casada acusada de adultério não comprovado objetivamente, na literatura brasileira, após a publicação de Dom Casmurro, descenderia de Capitu). Extravagante ter Giannetti afirmado a conexão e o parentesco entre as personagens, porque ele mesmo admite, mais adiante, que Matilde, a esposa suspeita e suspeitosa, parecendo não ter mistério algum, a não ser o seu súbito desaparecimento no plano da diegese, "não tem vida interior", outro ponto negativo para Chico Buarque, se de fato ele realmente pretendeu tal enlace. O próprio Eulálio - Giannetti não diz, mas parece querer apontar para isso - está mais para Brás Cubas do que para Bentinho, porque "os Eulálios senhoriais são calhordas”, estão longe, pois, do aristocratismo de Bento Santiago, não se fixam em algo só, nem na vida social, nem nos amores:

O seu bisavô paterno, feito barão por dom Pedro 1, traficava escravos moçambicanos; o seu bisneto, nascido em hospital do Exército onde os pais comunistas estavam presos pela ditadura, morre assassinado num motel; o derradeiro Eulálio, tataraneto do narrador, é traficante de drogas para a elite carioca. Do barão negreiro ao baronato do pó, o ciclo se fecha. É "o fim da linha dos Assumpção”. (GIANNETTI, 2009, p. 7)

Giannetti responsabiliza, por fim, a feitura do próprio romance escrito em primeira pessoa, talvez o arcabouço mais perigoso para o ficcionista:

[...] A primeira pessoa confessional é um gênero exigente. Os delírios da decrepitude de Eulálio são fiéis à vida, mas a situação narrativa do autor não convence. Não se sabe por que 
ele conta sua história e, menos ainda, como o relato se fixa e vira texto. (GIANNETTI, 2009, p. 7; o grifo é meu)

Ora, Giannetti não vê razão para o próprio relato - o que equivale a dizer que o romance é um luxo desnecessário, já que a narrativa (o tal "relato"), conduzida na primeira pessoa, "não convence" —, e, portanto, a dita "alta carpintaria literária" está abalada desde a raiz, parecendo haver aí uma grande contradição nos termos do ajuizamento do livro. O leitor crítico, diz Giannetti, nem sabe por que Eulálio conta sua história. E, pior do que isso, esse narrador impossível se atreve a transformálo em romance. Dessa maneira, Giannetti encontra-se mais distanciado do que Schwarz da grife Chico Buarque; e, consequentemente, o ato crítico sai preservado, mais "verdadeiro"; ou, pelo menos, não tão deslumbrado, sendo, pois, qualquer tentativa de aferir semelhanças ou coincidências com Machado de Assis mera impressão ou sugestão do crítico, sem maior apoio na empiricidade da obra. Sim, impressionismo da leitura crítica, sem dúvida; vontade de fazer valer o sentimento do crítico, sua marca pessoal, sua subjetividade, muito além das possibilidades oferecidas pelo texto criticado; vontade de o crítico sair mais bem iluminado nessa empreitada do que o próprio texto que critica, por razões que só o crítico poderia declarar.

Seria a causa desse estado o cruzamento que hoje se estabelece entre a crítica do jornal e a crítica universitária, sem separação rígida de fronteiras, como havia antes? Essa pergunta serve também ao entendimento da crítica maneirista, feita para revistas não universitárias (como Cult, Bravo, Piauí, Conhecimento Prático Literatura, Conhecimento Prático Língua Portuguesa, entre outras):

Para encerrar o debate - inútil dizer que de modo muito provisório - seguem-se algumas considerações finais. Elas ensaiam repensar, à luz de todo o anterior, uma hipótese insistente a respeito do tipo de tensão que mais presidiria 
à nossa modernidade crítica. . E que, a nosso ver, já não dá conta dos acontecimentos. A hipótese segundo a qual essa modernidade surge do encontro entre a especialização e o impressionismo, a objetividade do crítico-scholar e a preponderância para a crônica do crítico de rodapé, com seu ego avantajado. (MOTTA, 2002, p. 190).

As razões para justificar o frame da personalidade do crítico de jornal, hoje, filiam-se não ao manejo de uma teoria ou um referencial de peso, mas a uma exacerbação da sua imagem emoldurada eventualmente pela mídia televisiva e jornalística (impressa e eletrônica), situação ampliada e favorecida pela internet e pelos programas culturais que são transmitidos pela rede estatal de televisão. Muitos jornalistas chegam até a competir com atores de telenovela e de cinema a prerrogativa da aparição pública e seu endeusamento (o que não é o caso nem de Schwarz nem de Giannetti, bem mais discretos, embora tal situação repercuta no âmbito geral da sociedade brasileira que, para crer na palavra do especialista, muitas vezes aguarda os quinze minutos de fama a que o "homem das letras" teria direito).

Certamente uma visão de mundo dada pela profissão se impõe - as pessoas parece não terem convicção própria, mas aquela fornecida e moldada pela profissão que exercem (o médico quer pensar como médico em qualquer momento da vida diária, empurrando nos diálogos que mantém com os não médicos os jargões da profissão; igualmente o crítico literário quer falar como teórico e crítico o tempo todo, mesmo que não se sirva dos jargões especializados, principalmente em textos menos ambiciosos, como os de jornal). Isso é o império da personalidade talhada pela profissão; ou, se se quiser, trata-se da inscrição da subjetividade do indivíduo em dada "ordem do discurso", no sentido foucaultiano, na qual essa subjetividade é formada. A eventual aproximação de interpretações entre Schwarz e Giannetti, até criando a 
sensação de que um responde ao outro, como se estivessem ambos numa mesa-redonda de congresso, seja para acatar o outro, seja para opor-se-lhe, resulta dessa "visão de mundo" que a subjetividade moderna, em torno da noção de profissão, foi capaz de engendrar:

Ou seja, a profissão passa a ocupar um enorme espaço em suas vidas e se torna o elemento fundamental para a construção da identidade dessas pessoas. $\mathrm{E}$ a escolha desse papel como o principal em suas vidas vai gerar um "estilo de vida" e uma "visão de mundo" particulares, de acordo com Gilberto Velho [ver o seu Individualismo e cultura, de 1987]. A percepção da sociedade e sua compreensão, assim como a maneira de viver, vão estar profundamente influenciadas pela profissão. Não apenas em termos práticos, mas no aspecto existencial e simbólico. (TRAVANCAS, 2001, p. 24).

Por essa "visão de mundo", por exemplo, é de bom tom aproximar Chico Buarque de Machado de Assis, ainda que pelo menos um dos críticos examinados não pareça tão confiante em tal conjunção. Se - comparados esses dois textos publicados no caderno "Ilustrada" — o de Eduardo Giannetti, economista, tivesse sido assinado por Roberto Schwarz, doutor que atua na área de letras, nada haveria de espantar; o contrário é que chama atenção, mesmo com algumas semelhanças entre eles, o que faz entender que, apesar também das diferenças, subsiste com efeito uma "visão de mundo" da crítica literária - machadiana que, não raro, é capaz de ver chifres em cabeça de cavalo. E o engraçado, nesse "troca-troca" entre os autores, é que, coincidência ou não, parece que esses dois articulistas da Folha tiveram acesso um ao texto do outro antes de ser publicados. Pois, no título que deu, "Brincalhão, mas não ingênuo", Schwarz, como se respondesse a um possível ataque de Giannetti, se contrapõe à posição assumida pelo crítico-economista, negando o que este vê de ingenuidade no narrador Eulálio. Diz Giannetti: "O valor supremo de 
Eulálio, um oportunista ingênuocercado de aproveitadores espertos por todos os lados, é se dar bem a qualquer preço" (um momento, e esse Eulálio se parece com Bentinho? Ou com Brás Cubas, ao menos?). Schwarz diz claramente, no título, que Eulálio nada tem de ingênuo. E Giannetti arremata, como se mandasse a tréplica para Schwarz: em livro assim, como Leite derramado, com tanto índice de desmascaramento dos tipos mais vis da sociedade brasileira encastelados na sua camada mais alta, desde o Segundo Reinado, “a sociologia festeja, mas a filosofia rasteja”. Alusão ao sociólogo Roberto Schwarz?

Há algo pior ("a filosofia rasteja”) a ser dito de um romance em que "o conjunto do time e o desenrolar da peleja", segundo as últimas palavras de Giannetti, comparando o livro a uma partida de futebol, "deixam a desejar"? Isso vem de encontro ao que Giannetti mesmo disse no início do artigo sobre a construção de Leite derramado, "alta carpintaria literária", e mais para o fim, “a trama do ato de contar é tecnicamente débil — não para em pé”, em flagrante contradição entre os termos, voltando-se, em tudo o mais, lá e cá, contra o tom de encantamento destilado por Schwarz na consideração que este faz do romance de Chico Buarque.

Eis aí um destacado estudioso e especialista em letras (sem esquecer que a formação original de Schwarz se deu no campo das ciências sociais) que, pelo que se vê, poderia ter escrito o texto do economista e cientista social e vice-versa (não me consta que Giannetti seja professor na área da literatura). O desconfiado Schwarz, que desconfia até do método de que se serve, poderia ter escrito "A vida desde o fim", que foi composto por Giannetti, cuja busca teimosa em não jogar loas ao romance de Chico Buarque tem muito do caráter do autor das melhores páginas de crítica dialética já escritas neste país. Tal fato só parece confirmar a tese de que, na chamada pós-modernidade - em que as diferenças se autoimolam e se vão com os primeiros ares da madrugada (assim como, no dizer de Giannetti, "o romance se desmancha em sopro assim que termina”), nada parecendo de mais substancioso restar - 
não creio ser de muita valia, ao contrário do que pensa Silviano Santiago, chamar o crítico-professor universitário vinculado a programas de pós-graduação em letras a participar, de modo sistemático, dos grandes jornais e revistas de circulação nacional e até internacional, "em benefício da literatura, da universidade, da imprensa, do público e até em benefício próprio" (SANTIAGO, 2008, p. 156). A pátria ou não pode ou não quer ser salva.

Hoje, pode-se perguntar, Sérgio Milliet e Álvaro Lins se dariam bem no contexto das análises naturalmente apressadas, destinadas, ao que parece, a brindar as editoras e os autores de prestígio? As editoras e os interesses comerciais, mais vivos em época de globalização e de hegemonia da mídia eletrônica sobre a mídia impressa, não poderiam afetar, assim, sua produção crítica, fazendo descer ou desequilibrar-se sua qualidade interpretativa? Ainda: um atento e vigilante Afrânio Coutinho conseguiria agora o antídoto contra o autodidatismo; ou, em situação mais preocupante, garantiria, com o seu patrulhamento, que o crítico especializado, egresso dos programas de pósgraduação em letras, se saísse melhor do que o crítico não especializado? Uma espécie de briga de Roberto Schwarz contra Eduardo Giannetti ou, como pretendi sugerir, de Roberto Schwarz contra Roberto Schwarz? A convocação dos professores especialistas para ocupar o espaço dos suplementos literários resolveria, então, o quadro atual?

\section{Conclusão}

O que aconteceu com os escritores no século XIX, na aurora do folhetim - o romancista acompanhava o gosto do leitor passo a passo e submetia-se à limitação do tempo da escrita imposta pelo ritmo da escrita folhetinesca (Machado de Assis diz isso muito bem na "Advertência de 1874", pórtico do romance $A$ mão e a luva, que saiu originalmente em folhetim) - acontece hoje com a crítica. Confira-se o que disse então Machado sobre a importância do canal de comunicação e sua capacidade de alterar os caminhos do código literário: 
Esta novela, sujeita às urgências da publicação diária, saiu das mãos do autor capítulo a capítulo, sendo natural que a narração e o estilo padecessem com esse método de composição, um pouco fora dos hábitos do autor. Se a escrevera em outras condições, dera-lhe desenvolvimento maior, e algum colorido mais aos caracteres, que aí ficam esboçados. (ASSIS, 1976, p. 9; grifos meus).

As considerações que teci a respeito da crítica praticada em jornal, tal como esta foi mostrada com base no texto de Roberto Schwarz aqui estudado, obrigam a refletir sobre o que é e o que foi a crítica do jornal no Brasil: já se pôde um dia contar, como já fiz referência, com Álvaro Lins e Sérgio Milliet, que, mesmo "impressionistas" na avaliação de Afrânio Coutinho, por não terem tido especialização rigorosa e, ao contrário, por terem sido diletantes e autodidatas, eram, apesar disso, homens de sensibilidade e com experiência comprovada no âmbito da leitura literária erudita. Ao menos, eles tiveram — para usar a expressão de Brito Broca que Silviano Santiago traz à lembrança no seu artigo (2008) — “vida literária”.

Por outro lado, ainda que hoje o crítico universitário esteja "bem" formado, tem de enfrentar o desenvolvimento da tecnologia eletrônica, que a tudo invadiu, massificando o gênero ensaístico do jornal e rebaixando-o a um papel subalterno de guia do leitor médio ou de instrumento de divulgação das publicações recém-saídas do forno. As editoras visam, enfim, ao lucro e, por isso, muitas vezes escolhem o resenhista certo para divulgar o material literário que editam. Tal perspectiva - notadamente catastrófica para o terreno da crítica literária, porém fiel ao programa da indústria e do comércio livreiro, a que as pobres letras de um modo geral não estão imunes (e, parece, nunca estiveram, é só lembrar a era do mecenato) - não livra nem mesmo os bons críticos, como Roberto Schwarz, que, inquestionavelmente, tem sólida formação acadêmica. Ainda assim, parece, às vezes, que ele realiza uma crítica pouco empenhada, sobretudo 
ou principalmente quando migra do livro de ensaios para a revista, onde desempenha uma crítica maneirista medianamente alentada, e, mais grave ainda, para o jornal, onde a mitigação da aplicação dos valores do juízo crítico, neste tempo de brevidades e passagens céleres, é o tom mesmo que deve ser dado.

Poderia ser diferente? Isso se chama "crise", sejam quais forem os argumentos utilizados para falar desse tema (WILLER, 2001; OSORIO, 2005)? Pode ser que se tenha instalado um novo paradigma de crítica literária, para o qual não há conserto. Se ficar entendido que se está diante de um novo modelo de crítico - nem crítico scholarnem crítico jornalista, mas um híbrido —, então não haverá mais por que dar um piparote no nariz desse tão estimado profissional. Para que este artigo, enfim, não termine com um tom pessimista, digo que este é o novo retrato do crítico brasileiro - mais impressionista, menos scholar, mais próximo da vida que corre - , com todas as nuanças que a sociedade atual imprime à contemporaneidade. Desse modo, falar em crise não faz mais sentido; ou, enfim, redizê-la, sem, no entanto, cair de espanto. 


\section{Referências}

ARAÚJO, Carlos Magno. Amor à palavra. In: CASTRO, Gustavo de; GALENO, Alex (Orgs.). Jornalismo e literatura: a sedução da palavra. São Paulo: Escritura, 2002. p. 93-97. (Ensaios transversais, 18).

ASSIS, Machado de. A mão e a luva. 4. ed. São Paulo: Ática, 1976. (Bom livro).

CANDIDO, Antonio. O ato crítico. In: CANDIDO, Antonio. $A$ educação pela noite \& outros ensaios. São Paulo: Ática, 1987. p. $122-137$.

GIANNETTI, Eduardo. A vida desde o fim. Ilustrada. Folha de S.Paulo. São Paulo, 28 mar. 2009, p. 7.

GRANJA, Lúcia. Antes do livro, o jornal: "Conto Alexandrino". Luso-Brazilian Review. Madison: The University of Wisconsin Press, volume 46, number 1, 2009. p. 106-114.

MOTTA, Leda Tenório da. Sobre a crítica literária brasileira no último meio século. Rio de Janeiro: Imago, 2002.

NINA, Cláudia. Literatura nos jornais: a crítica literária dos rodapés às resenhas. São Paulo: Summus, 2007.

NUNES, Benedito. Crítica literária no Brasil, ontem e hoje. In: MARTINS, Maria Helena (Org.). Rumos da crítica. São Paulo: Itaú Cultural, 2000. p. 51-79.

OSORIO, Luiz Camillo. Razões da crítica. Rio de Janeiro: Jorge Zahar Ed., 2005.

PERRONE-MOISÉS, Leyla. Altas literaturas: escolha e valor na obra crítica de escritores modernos. São Paulo: Companhia das Letras, 1998.

SANTIAGO, Silviano. A crítica literária no jornal. In: $\neg \neg$ SANTIAGO, Silviano. O cosmopolitismo do pobre: crítica literária e crítica cultural. Belo Horizonte: Editora da UFMG, 2008. p. $156-166$. 
SCHWARZ, Roberto. Complexo, moderno, nacional, e negativo. In: SCHWARZ, Roberto. Que horas são?: ensaios. São Paulo: Companhia das Letras, 1987. p. 115-125.

SCHWARZ, Roberto. Sequências brasileiras: ensaios. São Paulo: Companhia das Letras, 1999.

SCHWARZ, Roberto. Casmurro abre o jogo. Piauí. São Paulo: Abril, ano 2, dez. 2008, p. 58-59.

SCHWARZ, Roberto. Brincalhão, mas não ingênuo. Ilustrada. Folha de S.Paulo. São Paulo, 28 mar. 2009, p. 6-7.

SOUZA, Eneida Maria de. Crítica cult. Belo Horizonte: Editora da UFMG, 2007.

SÜSSEKIND, Flora. Rodapés, tratados e ensaios. In: SÜSSEKIND, Flora. Papéis colados. 2. ed. Rio de Janeiro: Editora da UFRJ, 2003. p. 15-36.

TRAVANCAS, Isabel. O livro no jornal: os suplementos literários dos jornais franceses e brasileiros nos anos 90 . São Paulo: Ateliê Editorial, 2001.

VOVÔ best-seller. Veja. São Paulo: Abril, ano 37, no 45, 10 nov. 2004, p. 156.

WILLER, Claudio. A crise da crítica. Cult. São Paulo: Lemos Editorial, ano 5, no 49, ago. 2001, p. 10-16. 